\title{
THE INCLUSION OF VISUALLY IMPAIRED STUDENTS IN POST-GRADUATE PROGRAMMES: A PERSONAL AND POLITICAL PERSPECTIVE
}

Heidi Lourens

\section{INTRODUCTION}

Over the last two decades, the ideology and practice of inclusive education gained momentum across the globe. In 1994, 92 governments adopted the well-known Salamanca statement, whereby they agreed to include disabled children and students in regular learning environments (UNESCO 1994). Following this statement, inclusive policies provided the necessary impetus to include, amongst others, disabled students within institutions of higher learning (Beauchamp-Pryor 2012; Taylor 2004). As Taylor (2004:46) writes, "the number and experiences of students accessing HE will invariably be influenced by changes in legislation". Following in the footsteps of this global agenda, the South African government formally stated their commitment to welcome and accommodate disabled students in higher education through the introduction of Education White Paper 6: Building an Inclusive Education and Training System (Department of Education 2001). So, when South African tertiary institutions started opening their doors to disabled students, it was not a matter of granting them a favour; it was a matter of equal rights and quality education for all.

But what does "accommodate" and "welcome" really mean? How will universities know that they have adequately welcomed and accommodated disabled students on their grounds? Firstly, a welcoming and accommodating environment will translate into more disabled students crossing the borders of university campuses (Howell 2006). However, simply being there is not merely a sufficient measure of true inclusion. True inclusion will echo in the day-to-day experiences of disabled students when their equal participation is facilitated through adequate support and reasonable accommodations (Bantjes et al 2015; Howell 2005, 2006; Lourens \& 
Swartz 2016a). The responsibility does not rest on students to make the environment accessible or to adapt to an unwelcoming university climate; the onus rests on institutions of higher learning to facilitate the equal participation of all students entering their campuses (Department of Education 2001; Department of Higher Education and Training 2013; South African Government 2015).

This responsibility of universities does not end once disabled students obtain their first degree (Farrar, Young \& Denicolo 2007). When disabled students enrol for a postgraduate programme, they maintain the right to reasonable accommodations. This right is neatly captured in the recent White Paper on the Rights of Persons with Disabilities (South African Government 2015). One of its measures of inclusion reads, "[e]nsuring that persons with disabilities are able to access general tertiary education, vocational training, adult education and lifelong learning without discrimination and on an equal basis with others by, among others ensuring that reasonable accommodation is provided to persons with disabilities" (p. 83). It goes without saying that post-graduate support is included in the reference to lifelong learning.

In this chapter, I reflect on some of my experiences as a visually impaired doctoral student. I highlight the challenges I encountered, as well as those aspects that made the journey a bit easier (the latter I often stumbled upon by chance). Looking through a rights-shaped lens, I provide a brief overview of relevant factors that moulded my doctoral journey. Firstly, I explore the emotional and psychological underpinnings of the decision to ask for necessary support during postgraduate research. Hereafter, I reflect on practical accessibility difficulties and successes that I have encountered during this part of my educational career, such as (a) access to reading material; (b) access to participants and supervision - matters of transport; and (c) attending academic conferences. Lastly, I offer a reflection on the supervisorstudent relationship and the importance of flexibility. The thread that runs through all these sub-themes is the right to reasonable accommodations.

Unfortunately, there is no one-size-fits-all model to accommodate and include all disabled students in postgraduate programmes (Farrar, Young \& Denicolo 2007). This work provides a mere glimpse into my specific experiences as a visually impaired doctoral student. Yet it is my hope that, through my experiences, disabled students and disability-support staff might start to gain some insight into the rights and challenges of post-graduate studies for disabled students. 


\section{ENTITLEMENT TO SUPPORT: THOUGHTS ON IMPOSTERS AND STRUCTURE}

The decision to disclose an invisible disability is often not easy. For many disabled students, the anticipated social and academic costs of disclosure are simply too high. They often fear discrimination and exclusion by teaching staff and peers (Beauchamp-Pryor 2013; Elliot \& Wilson 2008; Foundation of Tertiary Institutions of the Northern Metropolis 2011; Kranke et al 2013; Lourens \& Swartz 2016b; Magnus \& Tøssebro 2013; Ngubane-Mokiwa 2013). Even though being open about their disability entitles them to reasonable accommodations, the very real fear of discrimination and exclusion sometimes outweigh the benefit of adequate support.

Since I am completely blind, it is almost impossible for me to pass as "normal" (Goffman 1963). I never had the option of concealing my disability and, partly because of this visibility, I comfortably requested reasonable accommodations during my undergraduate years. But, when I embarked on a doctoral study in 2011 - my first dissertation-based university programme - I lost the confidence to ask for support. My disability was still visible, but I felt less entitled to admit that I still needed reasonable accommodations. Farrar (2006) comments on the difficulty of disclosure during postgraduate studies, as the stakes are higher at these levels in terms of time, energy and intellect invested, as are the expectations of both students and staff involved. There were two aspects to the doctoral journey that lead to my reluctance to request support. Firstly, the unstructured nature of writing a dissertation blurred the scope and boundaries of reasonable accommodations. Secondly, I carried with me the erroneous assumption that I would not deserve a doctoral degree and the title that comes with it if I asked for support. In the following few paragraphs, I will briefly elaborate on these two aspects.

Usually, an undergraduate programme is highly structured. My three-year Bachelor of Arts Humanities degree was no exception. I attended lectures, completed assignments and wrote examinations. It was often the latter that hurriedly urged and "allowed" me to request support. Examinations that loomed around the corner felt like solid grounds for requesting accessible course material and extra time to complete assessments. Because I had to write examinations, it felt reasonable and legitimate to ask for reasonable accommodations.

And then I enrolled for a doctoral programme. Suddenly there were no formal lectures, no immediate assessments and no imposed deadlines. I mostly worked from home and, while drinking one steaming cup of coffee after the next, I brewed over my next sentence or paragraph in solitary confinement. While I clearly needed some level of support, I rarely thought about my need for reasonable accommodations. At the time, it was unclear to me why and for what I needed any form of support. As 
previously mentioned the lack of intermittent examinations and frequent assignments clouded my judgment on this matter. But, as it will become clear in this chapter, the presence or absence of frequent examinations does not measure the urgency or need for reasonable accommodations. Even though my doctoral programme was unstructured and the examination was, for the most part, in the distant future, I nevertheless needed accommodations. A doctoral candidate in a study by Farrar (2006:176) captures this need for support beautifully when she remarks, "[i]n theory research study with a physical-mobility impairment should be easier than undergraduate study. ... However, and it's a big however, in practice it is much, much harder. Research study is a lonely, isolating and anxious experience at the best of times. Doing it with an impairment multiplies those factors".

Having said this, I strongly believe there was something that weighed heavier; something that spoke louder than the structure of the doctoral degree programme. It was my beliefs around entitlement and worthiness. I firmly believed that the less I asked for assistance, the more the university, the academic department and my supervisor would recognise that I really deserve the title of "doctor". I believed that asking for too much support would be a clear sign that I was not worthy of this title. True to the imposter syndrome, first described by Clance and Imes (1978:241), I was scared to be "found out" for my "intellectual phoniness". This syndrome is not uncommon amongst doctoral students who could be considered different from their university counterparts (Gardner \& Holley 2011 ).

As all other postgraduate disabled students in South Africa, I undoubtedly had the right to request support. This right is clearly stipulated within inclusive policies such as White Paper 6 on Inclusive Education (Department of Education 2001), the White Paper on Post-school Education (Department of Higher Education and Training 2013) and the White Paper on the Rights of Persons with Disabilities (South African Government 2015). As I gradually made my way through my doctoral journey, I learned that neither the university nor my supervisor would have thought less of me if I asked for help. Ironically, it was the insight and understanding of my research supervisor that, in many regards, gradually provided me with the confidence to request accommodations.

In the following sections, I will reflect on the specific accommodations I needed to successfully complete my doctoral degree. The gaps in provision and the facilitating factors that aided my journey will be illuminated. I will also show the ways in which my uncertainties and reluctance to request reasonable accommodations permeated various practical parts of my journey. 


\section{ACCESS TO THE WRITTEN WORD: POVERTY IN THE CURRENCY OF RESEARCH}

Access to the written word, even in this electronic age, remains a challenge for visually impaired persons (Watermeyer 2014). In one of his recent articles, Brian Watermeyer (2014) critically dissects the phenomena of the "book famine" and the psychological ramifications thereof. Growing up with a degenerative visual impairment, he experienced the acute pain of losing the ability to feast on any book he wanted to read. He movingly writes, "[t] he words were slipping away, and with them my periscope into the world. Losing the words felt like being left behind, left by myself. ... Suddenly I had to survive on a little less each day, and then none at all. ... When one's soul has experienced a banquet, it is hard to be thankful for scraps from the kitchen door" (Watermeyer 2014:3).

These words of Watermeyer echo my disappointing experiences with the written word. From a very young age, I was left with no choice but to choose from a small collection of accessible books. My experience of the "book famine" was brought into sharp focus during my doctoral research - books mattered, not just because I loved them, but because I needed them. Obtaining a doctoral degree required intensive and extensive reading (Farrar, Young \& Denicolo 2007). I was no longer able to carefully and strategically select course materials to successfully complete assignments as I did during my undergraduate years. For my doctoral studies, I had to ensure that I read as much as possible to cover my field. In this section, I will briefly discuss some challenging encounters with printed and online texts. I will also provide a brief overview of those factors that actually facilitated, and those factors that could have facilitated my access to the written word.

A physical book, the printed pages of a readable text, remains unreadable to me. The promise of secrets within unreadable pages evaporates into nothingness in my hands. Almost nowhere is this awareness more acute than in the labyrinth of a university library. I usually asked friends to accompany me to the library and help me browse through books. All the while I remained fully aware of the time-consuming nature of this exercise, leaving me unable to shake off the guilt I felt towards my helpers. Once again, I fully agree with Watermeyer when he writes, "I remember wandering down a library corridor around the beginning of my first year, with a surreal awareness that I could not extract knowledge from even one of the millions of items that surrounded me. I was supposed to be able to read, and my illegitimacy made me fearful" (Watermeyer 2014:3).

Scanning printed material into an accessible, digital format remains one of the ways in which visually impaired persons can access written text. While there was an excellent scanning service at the university where I studied, textbooks for undergraduate 
students were their first and most urgent priority. The urgency of undergraduate examinations, coupled with the reality of limited staff, overshadowed my need for access to research material (Ngubane-Mokiwa 2013; Seyama 2009). In the end, I scanned most of my own texts. Of course, this endeavour took up a tremendous amount of precious research and leisure time. I remember that plummeting sensation in my stomach when I realised that a book that took hours to scan was not useful for my research. On the fortunate occasion when I discovered that a text was indeed useful, I had to make sense of badly scanned material.

Online materials were, and still are, more accessible than printed texts. Browsing the university library database was a far more pleasant experience than navigating through the hard copies of books in the physical library. Yet not all online materials are equally accessible. For example, my screenreading software, Jaws for Windows, is incompatible with .pdf image files (Mokiwa \& Phasha 2012; Ngubane-Mokiwa 2013). When the software unyieldingly announced, "page is empty" I had to print the document and scan it before I was able to read it.

Given all these struggles with the written word, it might seem like finding accessible reading materials will always be an insurmountable hurdle for visually impaired students. While this may be partially true, there are some factors that made this challenge a bit easier. The insight of my research supervisor was one of them. To a large extent, he expertly narrowed down the scope of my reading and pointed me to the most essential texts for my research. And, in those areas where he was unable to assist, he put me in contact with people who were able to help me such as the university librarian. Perhaps he suspected that I found it difficult to ask for help, because he took it upon himself to request support from the university librarian.

Having said this, it was not always possible for my supervisor to fill in the blanks of my silences. My reluctance to ask for appropriate and much-needed support sometimes simply meant that I had to continue without it. After I completed my doctoral research, many disabled students informed me that they requested, and was granted, an assistant to help them with reading-related challenges. I regret never requesting for this reasonable accommodation - someone to help me browse library books, scan reading materials, ask for electronic books from publishers and browse the internet. Simply asking for an assistant would have saved me valuable time.

In short, I found it challenging to comfortably navigate my way through postgraduate research, since I often lacked the currency for it, namely readable texts. The insight of my supervisor often steered me into the right direction and narrowed the scope of my reading, while an assistant would have made my journey a little bit easier. 


\section{GETTING THERE: NOTES ON SUPERVISION AND RESEARCH INTERVIEWS}

Access to transport is often an inherent requirement of the research process. Data often needs to be collected on various sites and within different towns or cities. And, since a doctoral programme is in most instances not a residential degree, it might also be necessary to drive to the university to attend supervisory meetings. This nature of a doctoral programme might pose some obvious challenges to students with a visual impairment. In South Africa, public transport is far from ideal. While the larger cities have some public transport options, the university where I studied was in the countryside where public transport is mostly unreliable and unsafe (Lourens 2016). I believe that some pre-doctoral planning and the flexibility of my research supervisor circumvented most of my potential transport challenges.

The research design of my study was carefully planned and strategically selected (Farrar 2006). To a large extent, the question, "would I be able to physically reach my target population" guided and filtered my research topic and design. In the end, I decided to collect data from disabled students at the university where I studied. In this regard, transport was not an issue. Unfortunately, I was unable to shape my research entirely around my transport difficulties; I was also required to interview students at a nearby university (approximately 30 kilometres away). Reaching this destination contributed to many sleepless nights. I anxiously called family members, friends and acquaintances to ask for their support. In the end, several people offered to take me to the university and I refunded them from study bursaries. (Fortunately, there are many bursaries available for disabled students. For example, the National Research Foundation offers an extensive bursary for disabled postgraduate students.) Requesting an assistant with a driver's license would have spared me the long and anxiety-provoking search for a driver. In addition, it would have lessened the guilt I felt towards people who volunteered their support.

After I conducted all my research interviews, I thought that my transport challenges were something of the past. It was not. During the write-up phase of my research, I had to move to another town for my husband's work. However, during the same year, my research supervisor took a one-year sabbatical and suggested that we have telephonic supervisory meetings. This eliminated the need for me and my supervisor to travel to the university for meetings.

In summary, potential transport difficulties were largely circumvented through the flexibility of my research supervisor, adequate and careful planning of research design and sufficient study bursaries. Once again, I firmly believe that I was entitled to ask disability support staff to assist me with some of these challenges, for example assigning an assistant to help with transport. 


\section{TRAVELLING ABROAD: NOTES ON ACADEMIC CONFERENCES}

Presenting research findings at national and international conferences is often a component of postgraduate research (Farrar 2006). With me it was no different. In 2013, halfway through my doctoral research, my research supervisor encouraged me to present at an academic conference in Austria. I had mixed feelings. On the one hand I was grateful and overwhelmingly excited about the prospect of travelling abroad and meeting academics with the same research interests as myself. But I was also nauseatingly worried about the prospect of being alone in a foreign country with a visual impairment my only familiar travelling companion. Who would assist me during the flight? Who would assist me from one flight to the next after a stop-over? Who would take me to the hotel, to the conference venue and to different rooms within the venue? How would I know where to go? As the date of my departure drew closer, these questions feverishly raced through my mind. Thankfully everything went smoothly. I indicated my disability on my flight ticket and the assistance was flawless. On the first day of the conference, I met someone who offered to help me throughout the conference week. In hindsight, hoping for the best is not the ideal way of approaching an upcoming conference.

Now, three years later and with many trial and errors behind me, I finally know how to approach the prospect of an academic conference. Firstly, as I have done on that very first flight to Austria, I indicate my disability on my flight ticket. Secondly, I email the conference organisers and explain the extent of my impairment. I always enquire whether they could provide me with someone who would assist me during the conference. Not once did a conference refuse to provide me with such assistance. Looking back, I think it would have been helpful to enquire to what extent university disability staff members would have been able to assist me. Helpful advice would have spared me many anxiety-provoking conference attendances.

\section{A LAST NOTE ON THE RESEARCH SUPERVISOR}

Disabled postgraduate students in the United Kingdom identified their relationship with the research supervisor as the most important vehicle for success (Farrar, Young \& Denicolo 2007). I wholeheartedly agree. Throughout this chapter I have continually emphasised the ways in which my research supervisor's insight, flexibility and empathic understanding contributed to the successful completion of my doctoral studies. He narrowed down the scope of my research, insightfully offered support and was flexible enough to allow telephonic supervisory meetings.

Possibly the most important advice I could give to disabled students who want to pursue doctoral research would plainly be to choose the right supervisor. This 
would entail a predoctoral meeting with the potential research supervisor. Even if supervisors are not familiar with disabilities, a mere willingness to meet, learn and adapt is probably a good indicator that he or she will be a good team member.

\section{CONCLUSION}

Embarking on postgraduate research is often a challenging journey for disabled students. While the support needs of disabled students take on a different shape and size during this phase of their studies, their right to reasonable accommodations remains unchanged. The responsibility still rests on universities to facilitate the lifelong learning of disabled students.

I have shown, through reflections on my own research journey, the ways in which I had to adapt to the research process. I had to scan many of my readings, organised transport for data collection and hoped for a pleasant and accessible stay at conference venues. I missed out on many supportive structures, simply because I never asked for it. Having said this, I believe that some formal gesture from disability support staff would have given me a higher sense of entitlement and would have strengthened my voice to ask. While they may maintain an unwavering commitment to support disabled students, the latter might not be aware of this continual support and their right to ask for it. I believe that a small but formal reminder could make a significant difference in the lives of disabled postgraduate students.

\section{ACKNOWLEDGEMENT}

I would like to thank my research supervisor, Prof Leslie Swartz, for his unwavering support throughout my doctoral research. Thank you for making this potentially lonely process feel like teamwork.

\section{REFERENCES}

Bantjes, J., Swartz, L., Conchar, L., \& Derman, W. (2015). "There is soccer but we have to watch": the embodied consequences of rhetorics of inclusion for South African children with cerebral palsy. Journal of Community and Applied Social Psychology, 25:474-486. http://dx.doi.org/10.1002/casp.2225

Beauchamp-Pryor, K. (2012). Changes in the political and policy response towards disabled students in the British higher education system: A journey towards inclusion. Scandinavian Journal of Disability Research, 14(3):254-269.

http://dx.doi.org/10.1080/15017419.2011.574840

Beauchamp-Pryor, K. (2013). Disabled students in Welsh higher education: A framework for equality and inclusion. Rotterdam, The Nederlands: Sense Publishers.

http://dx.doi.org/10.1007/978-94-6209-344-7 


\section{POSTGRADUATE STUDY IN SOUTH AFRICA}

Clance, P. R., \& Imes, S. A. (1978). The imposter phenomenon in high achieving women: Dynamics and therapeutic intervention. Psychotherapy: Theory, Research, and Practice, 15:241-247. http://dx.doi.org/10.1037/h0086006

Department of Education. (2001). Education White Paper 6 Special Needs Education Building an Inclusive Education and Training System. Pretoria, South Africa: Department of Education.

Department of Higher Education and Training. (2013). White paper on post-school education and training. Available online at http://www.dhet.gov.za/SiteAssets/Latest\%20News/ White\%20paper\%20for\%20post-school\%20education\%20and\%20training.pdf

Elliot, T., \& Wilson, C. (2008). The perceptions of students with hidden disabilities of their experience during transition to higher education. East of England Research Project. Available online at http://www.impact-associates.co.uk/hidden disabilities.html

Farrar, V. (2006). Equal to the task: disability issues in postgraduate research study. In M. Adams \& S. Brown (Eds.), Towards inclusive learning in higher education: Developing curricula for disabled students (pp. 176-187). London, UK: Routledge.

Farrar, V., Young, R., \& Denicolo, P. (2007). Supervising disabled research students. London: Society for Research into Higher Education.

Foundation of Tertiary Institutions of the Northern Metropolis (FOTIM) (2011). Disability in higher education project report. Available online at http://www.uct.ac.za/usr/disability/ reports/progress_report10_11.pdf

Gardner, S.K., \& Holley, K.A. (2011). "Those invisible barriers are real": The Progression of First-Generation Students Through Doctoral Education. Equity and Excellence in Education, 44(1):77-92. http://dx.doi.org/10.1080/10665684.2011.529791

Goffman, E. (1963). Stigma: Some notes on the management of spoiled identity. Harmondsworth, Penguin.

Howell, C. (2005). Higher Education Monitor. South African Higher Education Responses to Students with Disabilities. Equity of Access and Opportunity? Monitoring and Evaluation Directorate (CHE). Pretoria, South Africa: Council on Higher Education.

Howell, C. (2006). Disabled students and higher education in South Africa. In B. Watermeyer, L. Swartz, T. Lorenzo, M. Schneider, \& M. Priestley (Eds.), Disability and social change: A South African agenda (pp. 165-178). Cape Town, South Africa: HSRC Press.

Kranke, D., Jackson, S. E., Taylor, D. A., Anderson-Fye, E., \& Floersch, J. (2013). College student disclosure of non-apparent disabilities to receive classroom accommodations. Journal of Postsecondary Education and Disability, 26(1):35-51.

Lourens, H., \& Swartz, L. (2016a). Experiences of visually impaired students in higher education: bodily perspectives on inclusive education. Disability and Society, 31 (2):240-251. http://dx.doi.org/10.1080/09687599.2016.1158092

Lourens, H., \& Swartz, L. (2016b). 'It's better if someone can see me for who I am': stories of (in)visibility for students with a visual impairment within South African Universities. Disability and Society, 31 (2):210-222. http://dx.doi.org/10.1080/09687599.2016.1152950

Magnus, E., \& Tøssebro, J. (2013). Negotiating individual accommodation in higher education. Scandinavian Journal of Disability, 16(4):316-332.

http://dx.doi.org/10.1080/15017419.2012.761156 
Mokiwa, S. A., \& Phasha, T. N. (2012). Using ICT at an open distance learning (ODL) institution in South Africa: The learning experiences of students with visual impairments. Africa Education Review, 9(1):136-151. http://dx.doi.org/10.1080/18146627.2012.755286

Ngubane-Mokiwa, S. A. (2013). Information and communication technology as a learning tool: Experiences of students with blindness. (Unpublished doctoral dissertation). University of South Africa, Pretoria: South Africa.

Seyama, L. G. (2009). Information seeking behaviour of students with visual impairments: A case study of the University of KwaZulu-Natal, Pietermaritzburg. (Master's dissertation). University of KwaZulu-Natal, Pietermaritzburg: South Africa.

South African Government (2015). White Paper on the Rights of Persons with Disabilities. Available online at http://www.gov.za/documents/white-paper-rights-persons-disabilitiesofficial-publication-and-gazetting-white-paper

Taylor, M. (2004). Widening participation into higher education for disabled students. Education and Training, 46(1):40-48. http://dx.doi.org/10.1 108/00400910410518214

The United Nations Education, Scientific and Cultural Organization (UNESCO) (1994). The Salamanca Statement and Framework for Action on Special Needs Education. World Conference on Special Needs Education: Access and Equality. Paris: UNESCO.

Watermeyer, B. (2014). Freedom to read: a personal account of the 'book famine'. African Journal of Disability, 3(1):1 -6. http://dx.doi.org/10.4102/ajod.v3i1.144 